\title{
ANALYSIS OF CAPITAL STRUCTURE AND FINANCIAL PERFORMANCE IN THE JORDANIAN INSURANCE SECTOR \\ Zelhuda Shamsuddin $^{1 *}$, Al Majali Muhammad Ahmad Kamel ${ }^{2}$, Wan Mohd Nazri Wan Daud ${ }^{3}$, Wan Sallha Yusoff $^{4}$ \\ ${ }^{1 * 3}$ Faculty of Business and Management Sciences, Universiti Sultan Zainal Abidin, Terengganu, Malaysia; ${ }^{2,4}$ School of \\ Business Innovation and Technopreneurship, University Malaysia Perlis, Perlis, Malaysia. \\ Email: ${ }^{1 *}$ zelhudasham@unisza.edu.my, ${ }^{2}$ mohannad2almajali@gmail.com, ${ }^{3}$ wanmnazri@unisza.edu.my, \\ 4wansallha@unimap.edu.my
}

Article History: Received on $20^{\text {th }}$ January 2020, Revised on $25^{\text {th }}$ April 2020, Published on $29^{\text {th }}$ June 2020

\section{Abstract}

Purpose of the study: This paper aims to examine the impact of capital structure and financial performance of listed insurance companies in Jordon.

Methodology: This study used secondary data that was collected from Amman stock exchange and annual report of the selected insurance companies from the year 2007-2017. The static panel data analysis technique is used to examine the impact of capital structure on firm's performance. The capital structure is measured using short-term debt, long-term debt, and equity financing. Whereas financial performance is measured using Return on Asset (ROA), Return on equity (ROE), and Tobin's Q.

Main Findings: The study findings suggest that capital structure influence the profitability of the listed insurance firms in Jordan. The results also reveal a significantly positive relation between long-term debt to total assets to profitability indicators, namely, return on assets (ROA), return on equity (ROE) and Tobin's Q. On the other hand, the results also reveal a short-term debt has a significant positive relationship with return on equity (ROE) and returns on assets (ROA). However, a relationship between short-term debt and Tobin's Q is not statistically significant.

Applications of this study: The result of this study may assist the insurance sector in Jordon in making decisions regarding capital structure, which is to significantly rely on equity financing or debt financing to reduce financing risk such as agency cost that borne by the equity holders of the Jordanian insurance firms.

Novelty/Originality of this study: The study noted that insurance firms generally play a crucial role in the economic development of every country. This study provides evidence that Jordanian insurance firms need to diversify their sources of financing and not rely significantly on debt financing, as the results prove that equity financing is a profitable source of financing.

Keywords: Jordon Insurance Companies, Capital Structure, Short-term Debt, Long-term Debt, Equity Financing, Financial Performance.

\section{INTRODUCTION}

Insurance companies are one of the components of the financial sector, which constitute the most substantial proportion of all sectors in the Jordanian economy. The Jordanian insurance sector plays a vital function to support the gross domestic product to strengthen the economic environment. One of the most important objectives of financial reforms in Jordon is to possess the financial performance of the insurance sector. Maximize performance also become one of the challenges faced by the firms to strengthen their financial positions to sustain and address the challenges of globalization. With diverse inclusive views on the financial performance and capital structure, thus this study continuously considers investigating the relationship of capital structure and performance of insurance firms in Jordon. The lack of research in the Jordon insurance sector relating to capital.

One of the main objectives of a firm is to maximize profitability, which means maximizing the wealth of owners or shareholders of the firm we know that many factors affect profitability and one of these factors is the essential decision making to an optimal level of capital structure which would enhance the firm's profit. Capital structure has an important role in determining a company's financial performance and fulfills the expectations of stakeholders who always demand the maximization of the value of the company's. Moreover, capital structure decision is critical for any organizations for maximizing return to the various stakeholders and also enhances the organization's ability to deal with its competitive market (Ali \& Nawab, 2016). Profitability is one of the most important objectives that companies seek to achieve in their different types and sizes, where profitability is a clear indicator of the strength of the company, its position, and its ability to survive in a highly competitive environment. Whereas the importance of the financing option, choosing either internal or external sources, is considered one of the most important with a direct impact on company performance (Zeitun \& Tian, 2007).

The capital structure refers to how the company finances its assets, both internally Sources and externally Sources. In other words, debt financing is short-term debt and long-term debt. The second source is equity financing, which is retained earnings and capital paid by the owners, the company must choose the right mix of stocks, debt, or securities. 
This mix is called the optimal capital structure that increases the interest of the company where the cost of capital is reduced and the value of the company increases (Abrar \& Javaid, 2016).

Choosing the ideal capital structure is one of the most sensitive financial decisions taken by management, which is based on comparing the advantages and costs of debt to equity, it is usually difficult for business organizations to determine the right mix of stocks and debt. This decision is crucially important to maximize returns to the various stakeholder level. The impact of such a decision is also important to the company's financial ability to cope with its competitive environment subsequently, determining the appropriate capital requirements and sources of fundraising is very important.

The capital structure choice is, for sure a fundamental choice for any business. Firms need finances to carry on their business operations and to maximize returns to various organizational constituencies. While this is also true for insurance companies, their main focus is somewhat different. The nature of the insurance business is to protect policyholders in times of accident through the minimization of loss. It does this by accepting premiums from policyholders and paying claims. As a result of this function, insurance firms have always been interested in whether the firm has enough money to fulfill their obligations towards the document holders. To manage risks, insurance firms must have effective ways of determining the appropriate amount of capital that is necessary to absorb unexpected losses arising from insurance claims and other operational risk exposures. (Takele \& Beshir, 2017; Ai \& Chi, 2019).

The study between capital structure and performance has aroused debates in most industry and apparently, the issue of capital structure is still unresolved. There are mixed results about the relationship between capital structure and performance. Some studies have argued that capital structure has a positive impact on performance; other studies found that capital structure has a negative impact on performance. Yet the analysis and evaluation of capital structure to insurance companies in Jordon are less analyze in this perspective.

This study provides insurance companies with a relevant indicator that would guide them to make efficient use of the resource base and most studies have previously focused on studying large sectors such as banks. Furthermore, no proper study had been done on the factors affecting the financial performance of small companies such as insurance companies. Moreover, some focused on the only analysis of financial performance, not on factors affecting capital structure on performance. Contrary to the previous studies conducted in Jordan, this study highlights market values in addition to accounting values. Therefore, Tobin's Q was used as one of the measures of performance for this study. Besides that, the market concentration variable was used as a control variable for this study; to measure competition in the product market.

The objective of this study is to study the impact of the capital structure on the profitability of insurance companies in Jordan, where the independent variable will be measured using three capital structure proxies, namely the short term debt, long term debt, and equity financing, which each is selected as a representative of internal and external financing for insurance companies, This study will use the accounting values to assess the performance of the company which is the return on asset (ROA), return on equity (ROE) and proxy to market performance which is Tobin's Q. The next section reviews the literature, followed by a discussion regarding methodology and the discussion on data and regression analysis. The last section is the conclusion.

\section{LITERATURE REVIEW}

The main objective of the company is to maximize the profits of the shareholders, so the company must take care to make the appropriate decisions that affect its profitability, the choice of capital structure is one of the most important financial decisions of firms which eventually affects the profitability of a firm. The connection between capital structure and performance has sparked the interest of researchers in finance lately. Many studies, such as (Shamsuddin et al 2018), (Olang 2017), and (Patjoshi 2016) have pointed the importance to study the relationship between capital structure and financial performance of companies.

Managers continuously try to make choices which will result to increase in firms profit avoiding those that have a negative effect on profits the capital structure decision is the vital one since the profitability of an enterprise is directly affected by such decision. Hence, proper care and attention need to be given while determining the capital structure decision (Alomari \& Azzam, 2017).

There are several alternative capital structures on which organizations can choose, where it can be either issue a large amount of debt or very little debt. The firm can issue convertible bonds, use warrants or arrange lease financing, sign forward contracts, or trade bond swaps. A firm can issue many distinct securities in countless combinations, as it attempts to figure out the particular blend that can maximize its overall market value (Martati \& Kusrihandayani, 2018). Several theories were proposed to explain the capital structure of organizations. Researchers in financial management has not figured out the ideal capital structure despite the theoretical appeal of capital structure. Prescriptions were the most outcome that academics and professionals have been able to achieve to satisfy short-term goals $\underline{\text { Zeitun \& Tian, }}$ 2014). The debt ratio is one of the measurements used to represent the capital structure (Hamid, \& Kamaruzzaman, 2015). 
On the other hand, using one assessment method to measure the capital structure is not sufficient, as it may lead to wrong results about the capital structure of the organization (Shubita \& Alsawalhah, 2012). Several types of research conducted previously used more than one method to measure the capital structure, for example, a combination of total debt to total assets, short-term debt to total assets and long-term debt to total assets as the proxies for the capital structure of the organization. (Ahmad \& Abdul Rahim, 2013).

This study used three proxies for the capital structure to figure out its relationship with organizations' profitability. Shortterm debt is also known as short-term or current liabilities this ratio shows that how much of total assets have been financed through short term loan and it is an account shown in the current liabilities portion of a company balance sheet this account is made up of any debt incurred by a company that is due within one year (Habib, et al. 2016).

These types of loans arise on a business's balance sheet when the company needs quick financing in order to fund working capital needs, and there are many types of short-term debt such as company's short-term bank loans and company's accounts payable and commercial paper (Ali et al., 2016). Short-term debt liabilities are required to be discharged in a year period. Alternatively, these cover those obligations whose liquidation is expected to be made out of current assets, as they are required to be paid at fairly definite dates which usually incurred in the ordinary course of business (Hamid et al., 2015).

A long-term debt ratio means the company is funding most of its ventures with debt which is payable after more than one year. If this ratio is too high, the company is at risk of bankruptcy if it becomes unable to finance its debt due to decreased income or cash flow problems since debt sums tend to be large, these loans take many years to pay off (Hirdinis, 2019). Companies with too much long-term debt will find it hard to pay off these debts and continue to thrive, since much of their capital is devoted to interest payments, making it difficult to allocate money to other areas (Ashraf, et al., 2017).

Long term debt (LTD) used as a measure of the company's capital structure and showed the percentage of assets financed with debt which is payable after more than one year (Habib et al. 2016). Long-term debt incorporates all liabilities other than the short-term debt and shareholders' equity. This typically includes large senior debts like mortgages and loans to purchase equipment or construct buildings (Revathy \& Sreekala, 2016).

Equity financing the second type of financing is equity financing or shareholders' equity is part of the total capital of a business; Equity financing includes common stock, preferred shares, or retained earnings (Revathy \& Sreekala, 2016). The company needs equity financing to expand the business more capital is needed, so the company issue shares to the general public, and the share issue is known as equity financing.

Equity financing does not require the company to issue collateral, and additional financing of shares does not increase the likelihood of financial distress. The only dividend is paid to shareholders if management decides. Also, equity financing does not create incentives for managers to replace risky projects. The main benefit of equity is that no payback is required by the company to shareholders and as compare to debt financing no interest payment is required (Zafar, et al.,2016). The motive of studying short term, long-term, and equity financing separately is to investigate the impact of the different types of financing options. Since the cost/benefits of short-term debt and long-term debt differ to a great extent, therefore, separate analysis can explain the relationship better (Hirdinis, 2014).

Gambo et al. (2016) studied the impact of capital structure on financial performance was examined among the cement industry firms in Nigeria. A total of 4 listed companies were employed as a sample in this study. Balanced panel data comprising 20 observations of the selected companies in the 2010-2014 period were analyzed. For analyzing the impacts of long term and short term debts on Return on Assets (ROA) and Return on Equity (ROE), the ex-post factor with two models was applied in this study. Meanwhile, the analyses were performed using descriptive statistics, correlation, and regression, and the results showed a statistically significant impact existing between long term and short term liability on return on assets (ROA) and return on equity (ROE).

Abeywardhana \& Krishanthi (2016) examined the effects of capital structure on manufacturing performance companies in the UK from 1998 through 2008. Secondary data were collected from published of manufacturing sector SMEs in the UK. Multiple regression analysis was employed with the aid of E-view statistical package. The independent variables for this study are capital structure measured Total debt to total assets, Long term debt to total assets, Short term debt to total assets, Short term debt to total debt and the performance is measured using the return on assets (ROA) and return on capital employed. The results of this study reveal that there is a significant negative relationship between capital structure and firm performance (ROA, ROCE), strong negative relationship between liquidity and firm performance, and a highly significant positive relationship between size and firm performance.

In Bangladesh, Siddik et al. (2017) examined the impact of capital structure on the Performance of Banks. Accordingly, the authors gathered data from annual reports published by 122 banks for the period between 2005 and 2014. The construct of performance, which was the dependent variable of this study, employed three proxies, namely ROA, ROE, and EPS. As for capital structure variables, which includes short term debt to total asset, total debt to total assets, and long-term debt to total assets. For the control variables, they encompassed liquidity, firm's size, and growth 
opportunities. Furthermore, in order to impart control on the impact of the macroeconomic state of affairs, this study utilized the variables of economic growth and inflation rate. From the results, the authors concluded a significant negative impact of capital structure variables on ROA and ROE.

In Pakistan, the link between capital structure and performance among non-financial companies was examined in Habib et al. (2016). Panel data of 10 years, (2003 to 2012) were employed in this study. Meanwhile, the independent variables of this study were as short-term debt to asset, long-term debt to asset, and total debt to the asset. On the other hand, the dependent variable encompassed return on assets (ROA) as a measure of performance. As for control variables, they were represented by the firm's size, sales Growth, and Growth Opportunity. Computation of size involved the log of sales, while the impact of debt on performance was ascertained using random effect regression analysis. In this study, the authors concluded a significant and negative linkage between short-term debt, long-term debt, total debt, and ROA.

In a similar context, the effect of capital structure on the performance of 46 families and 46 non-family listed Malaysian companies was examined (Hamid et al., 2015). A total of 276 financial year observations from annual reports were made covering the period from 2009 to 2011. Return on equity (ROE) was the study's dependent variable, while short-term debt (STD) and long-term debt (LTD), and total debt (TD) was assigned as the study's independent variables. Control variables were also employed in this study, and they were as follows: sales growth, industry types, and company size. The authors found a negative and significant link between debt ratio and performance. As suggested by the authors, profitable companies appeared to be more reliant on equity as major financiers to their operations.

Financial performance or profitability indicator can be influenced by the objective of the firm. Burja (2011) described an organization's profit or performance as the primary outcome of controlling several economic resources and utilize it within the operational, investment, and financing activities. Profitability is considered to be an outcome or result of an organization's operation. The organization's outcome is the difference between firm revenue and its expenditure. One of the key goals of any business is profit maximization. Managers constantly try to make decisions to maximize profit while eliminating those that have a negative impact on profits. The profitability of an organization is usually influenced by several factors, for example, capital structure, inflation rates, the organization size, competition etc. Ratios are being used to measure profitability which helps in summarizing huge volumes of financial data into understandable figures, Kirmi (2017). Many stakeholders utilize the organization's profitability ratios to generate profits that reflect the organization's performance.

The return on assets (ROA) and is also called return on investment and it is one of the most important measurements used to measure the company's ability to generate profits. (Anarfo \& Appiahene 2017) Return on assets ratio is an indicator of how effectively a company is using its assets to generate earnings before payment of taxes and dividends for example, current assets and fixed assets (Murniati, 2016). The higher the ratio obtained the more efficient the asset's management of a company because the company is earning more money on less investment (Suardana, et al., 2018).This measure provides an overview of the company's ability to obtain results on the financial resources invested by the company and this means that the management will be able to measure the financial performance and operational performance in the use of all resources owned by the company and it is used to measures the profit earned per dollar of assets. (Siddik, et al., 2017). ROA is employed to see the extent to which the combination of effects between margin and asset turnover rate (Murniati, 2016) The companies having profitability or high rate of return on investment use relatively smaller debt, higher returns enable the company to finance the majority of their funding needs using internally generated funds. ROA is most useful for comparing companies in the same industry, as different industries use assets differently. For example, the ROA for service-oriented firms, such as banks, will be significantly higher than the ROA for capital intensive companies, such as construction or utility companies (Martinkute \& Rinkeviciute, 2014).

The second indicator of performance is the Return on equity (ROE); it is a measure of financial performance calculated by dividing net income by shareholders' equity. Because shareholders' equity is equal to a company's assets minus its debt, this ratio means that how much profit earned for each dollar invested in the firm's stock (Anarfo \& Appiahene, 2017). Return on equity (ROE) indicates how much profit the company has generated using shareholder equity determines not only performance but also reflects the extent of the effectiveness of the management use of shareholders' investments (Marandu \& Sibindi, 2016).

A return on shareholder's equity is calculated to see the performance of owners ${ }^{\text {ec }}$ investment, the higher such ratio, and the more efficient is the performance of a firm. The shareholder's equity or net worth will include paid-up share capital, share premium and reserves and surplus less accumulated losses' return on shareholders' equity is calculated to see the performance of owners" investment, The higher such ratio, the more efficient is the performance of a firm (Zeitun \& Tian, 2014).

The third indicator of performance is Tobin's Q. Tobin's q ratio is defined as the ratio of the market value of the firm's assets to its replacement cost (Venugopal \& Reddy, 2016). The market value of a company's assets is measured by the market value of its outstanding stock and debt, while the replacement cost of assets is measured using their book value (Girod \& Whittington, 2017). Tobin's Q is defined as the total market value of company + liabilities divided by the total asset value plus liabilities (Singh, et al., 2018). 


\section{METHODOLOGY}

The data used in this study is extracted from the income statement and balance sheet of 19 Jordanian public insurance companies listed in the Amman Stock Exchange for the period 2009 to 2016. In order to identify the effect of capital structure on firms' performance. The regression analyses were used to analyse the relationship between capital structure and financial performance. This study model includes three proxies for capital structure: Equity financing (TQ), Long term debt (LTD), Short term debt (STD). The debt ratio is one of the measurements used to represent the capital structure. In addition, using one assessment method to measure the capital structure is not sufficient, as it may lead to wrong results about the capital structure of the organization (Zeitun \& Tian, 2014).

The regression model used is as follows:

\section{Equation 1}

$R O E$ it $=\beta 0 i t+\beta_{1} L T D i t+\beta_{2}$ Age it $+\beta_{3}$ Size it $+\beta_{4}$ Growth it $+\beta_{5} I N F i t+\beta_{6} G D P i t+\beta_{6} H H I+\varepsilon i t(1)$

$R O E$ it $=\beta 0$ it $+\beta_{1} S T D$ it $+\beta_{2}$ Age it $+\beta_{3}$ Size it $+\beta_{4}$ Growth it $+\beta_{5} I N F i t+\beta_{6} G D P i t+\beta_{6} H H I+E$ it (2)

$R O E$ it $=\beta 0$ it $+\beta_{1} E T Q$ it $+\beta_{2}$ Age it $+\beta_{3}$ Size it $+\beta_{4}$ Growth it $+\beta_{5}$ INF it $+\beta_{6}$ GDP it $+\beta_{6} H H I+E$ it (3)

\section{Equation H2}

$R O A$ it $=\beta 0 i t+\beta_{1} L T D i t+\beta_{2}$ Age it $+\beta_{3}$ Size it $+\beta_{4}$ Growth it $+\beta_{5} I N F i t+\beta_{6} G D P i t+\beta_{6} H H I+\mathcal{E} i t(1)$

$R O A$ it $=\beta 0$ it $+\beta_{1} S T D$ it $+\beta_{2}$ Age it $+\beta_{3}$ Size it $+\beta_{4}$ Growth it $+\beta_{5} I N F i t+\beta_{6} G D P i t+\beta_{6} H H I+E$ it (2)

ROA it $=\beta 0$ it $+\beta_{1}$ ETQ it $+\beta_{2}$ Age it $+\beta_{3}$ Size it $+\beta_{4}$ Growth it $+\beta_{5}$ INF it $+\beta_{6}$ GDP it $+\beta_{6} H H I+E$ it (3)

\section{Equation H3}

$T Q i t=\beta 0 i t+\beta_{1} L T D i t+\beta_{2}$ Age it $+\beta_{3}$ Size it $+\beta_{4}$ Growth it $+\beta_{5} I N F i t+\beta_{6} G D P i t+\beta_{6} H H I+\varepsilon$ it $(1)$

$T Q i t=\beta 0 i t+\beta_{1} S T D i t+\beta_{2}$ Age it $+\beta_{3}$ Size it $+\beta_{4}$ Growth it $+\beta_{5} I N F i t+\beta_{6} G D P i t+\beta_{6} H H I+E$ it (2)

$T Q I t=\beta 0$ it $+\beta_{1} E T Q i t+\beta_{2}$ Age it $+\beta_{3}$ Size it $+\beta_{4}$ Growth it $+\beta_{5} I N F i t+\beta_{6} G D P i t+\beta_{6} H H I+E$ it (3)

Where, LTD is long term debt to total assets, STD is short term debt, TQ is equity financing, ROA is the return on total assets, HHI is market concentration, INF is the inflation rate, Growth is assets growth, Size is the size of a firm, GDP) is Gross domestic product and Age is firm's Age.

\section{Determinants of variables}

Table 1: Variables of the study

\begin{tabular}{|c|c|c|c|}
\hline Variable & & $\begin{array}{c}\text { Variable } \\
\text { Measurements }\end{array}$ & References \\
\hline \multirow[t]{2}{*}{ Short term debt } & STD & short term debt & Ashraf et al. (2017) \\
\hline & & Total Assets & $\underline{\text { Habib et al. (2016) }}$ \\
\hline \multirow[t]{2}{*}{ Long term debt } & LTD & long term debt & Awuah (2016) \\
\hline & & Total Assets & \\
\hline \multirow[t]{2}{*}{ Equity financing } & ETQ & Total Equity & Zafar et al (2016) \\
\hline & & $\overline{\text { Total Assets }}$ & Soumadi\&Hayaineh (2012) \\
\hline \multirow[t]{2}{*}{ Return on equity } & ROE & Net Income & Siddik et al., (2017) \\
\hline & & $\overline{\text { Owner'equity }}$ & $\underline{\text { Marandu \& sibindi (2016) }}$ \\
\hline \multirow[t]{2}{*}{ Return on Assets } & ROA & Net Income & $\underline{\text { Suardana et al., (2018) }}$ \\
\hline & & $\overline{\text { Total Assets }}$ & $\underline{\text { Anarfo \& Appiahene (2017) }}$ \\
\hline \multirow[t]{2}{*}{ Tobin's Q } & TQ & The total market value of assets & Venugopal \& Reddy (2016) \\
\hline & & bool value of assets & Hasan \& Alam (2014) \\
\hline \multirow[t]{2}{*}{ Sales growth } & Growth & sales of current year - sales of previous year & Ali et al. (2016) \\
\hline & & sales of the current year & Getahun (2014) \\
\hline Firm's age & Age & Observation date - start date & $\underline{\text { Rouf (2015) }}$ \\
\hline Size of a firm & Size & Size $=\log ($ Total assets $)$ & $\begin{array}{l}\text { Hamid et al, (2015) } \\
\underline{\text { Tailab, (2014). }}\end{array}$ \\
\hline
\end{tabular}




\begin{tabular}{|c|c|c|}
\hline Inflation Rate & INF & $\begin{array}{c}\quad I R=\frac{p o-p i}{p i} * 100 \% \\
\text { po }=\text { current average price level } \\
\text { pi }=\text { price level a year ago }\end{array}$ \\
\hline
\end{tabular}

\begin{tabular}{lll}
\hline Growth & GDP & Abbas (2016)
\end{tabular}

$\begin{array}{lcc}\begin{array}{l}\text { Measures the } \\ \text { concentration }\end{array} & H H i=S i^{2} & \text { Moeinaddin et al. (2013) } \\ S i^{2}=\frac{x j}{\sum_{i}^{n}=1 \times j s} & \end{array}$

In the above equation, $x \mathrm{j}$ is the sales of firm $\mathrm{j}$, and $\mathrm{i}$

is the industry type

\section{DISCUSSION / ANALYSIS}

Table 2: Descriptive Statistic

\begin{tabular}{cccccc}
\hline Variable & Mean & Std Dev & Min & Max & Observations \\
\hline ROE & .1536691 & .1035403 & .0014667 & .5466462 & 190 \\
\hline ROA & .6098332 & 4724441 & .0012454 & 1.976518 & 190 \\
\hline TQ & 5004668 & .4005425 & .0314808 & 4.736377 & 190 \\
\hline LTD & .3878284 & .1712975 & .0175258 & 1.057972 & 190 \\
\hline STD & .2020391 & .1166065 & .0121702 & .7901996 & 190 \\
\hline ETQ & .4186921 & .1570226 & .000988 & .9236225 & 190 \\
\hline Size & 7.394795 & .2818901 & 6.826614 & 8.043415 & 190 \\
\hline Age & 29.81579 & 15.11658 & 1 & 66 & 190 \\
\hline Growth & .3409152 & .2914722 & .0015259 & .9387023 & 190 \\
\hline INF & .033 & .0159858 & .022 & .072 & 190 \\
\hline GDP & 3.26 & 1.627989 & 2 & 7.2 & 190 \\
\hline HHI & 8.373632 & 4.914034 & 3 & 6.82 & 190 \\
\hline
\end{tabular}

Table 2 shows the descriptive statistics of the variables of this study. Total observations come to $19 \times 10=190$ for the Jordanian insurance firms. The maximum return on equity (ROE) of Jordanian firms is $54.664 \%$ while the minimum shows of $0.1466 \%$. The maximum return on assets (ROA) of Jordanian firms is $197.651 \%$ while the minimum shows of $0.1245 \%$. It indicates that there will be a presence of high agency conflict in the Jordanian Insurance firms. It also indicates that the Jordanian Insurance sector is highly volatile, thus triggering low returns or losses. However, Tobin's Q of Jordanian firm is far better than the ROA and ROE. The maximum Tobin's Q is $473.637 \%$, implying that the market valuation of Jordanian firms is high. About the poor performance of ROE and ROA, it implies that the Jordanian Insurance sector is overvalued, which may lead to sizeable adverse selection and agency conflict relationship between the shareholders and the firm's managers.

Evidence in Table 2 shows that the performance of equity financing is better than the other two sources of capital structure (long-term debts and short-term debts). From the mean of the capital structure, equity financing in Jordanian firms represents $41.86 \%$ while debt financing represents $58.82 \%$ (both mean values for short term and long-term debt). This indicates that Jordanian firms practice the trade-off theory of capital structure to take the opportunity of the tax benefits of debts. However, the difference between the percentage of debt and equity financing (say 58.82\% minus $41.86 \%$ ) represent the financing risk or agency costs borne by the equity owners of the Jordanian Insurance firms.

\section{Regression Analysis}

This study used a static panel data model to measure the impact of capital structure and performance. The regression model was done using Stata software. Breush-Pagan LM is applied to choose the model between ordinary least square (OLS) and random effect. Whereas, Hausman test is used to choose the model between random effect and fixed effect. For all models, namely ROA, ROE and Tobin are the OLS model was selected as the best fit model, where the Null Hypothesis of Breush-Pagan LM is accepted, where the p-value is greater than 0.05 ., This study performed a diagnostic test of serial correlation and heteroscedasticity. There is no serial correlation problem in the OLS regression model. However, this study found a heteroscedasticity problem in the OLS regression model and used a robust option to rectify it. Here, this study discusses the result of robust specifications as shown in Table 3. 
Table 3: OLS Robust Regression Model

\begin{tabular}{|c|c|c|c|}
\hline Variables & $\begin{array}{c}\text { ROE } \\
\text { Equation } 1\end{array}$ & $\begin{array}{c}\text { ROA } \\
\text { Equation } 2\end{array}$ & $\begin{array}{c}\text { Tobin's Q } \\
\text { Equation } 3\end{array}$ \\
\hline \multirow[t]{2}{*}{ LTD } & $.3612977^{*}$ & $.4500929 *$ & $.3880491 *$ \\
\hline & $(0.000)$ & $(0.000)$ & $(0.000)$ \\
\hline \multirow[t]{2}{*}{ Asset Size } & $.3424456 * *$ & $.2385256^{* *}$ & $.4350189 *$ \\
\hline & $(0.001)$ & $(0.001)$ & $(0.000)$ \\
\hline \multirow{2}{*}{ Firms Age } & .0002876 & .0003107 & $-.0014123 * *$ \\
\hline & $(0.545)$ & $(0.635)$ & $(0.030)$ \\
\hline \multirow[t]{2}{*}{ Sales Growth } & $.4274705^{*}$ & $.3753311 *$ & $.2390637 * *$ \\
\hline & $(0.000)$ & $(0.000)$ & $(0.008)$ \\
\hline \multirow[t]{2}{*}{ Inflation Rate } & -.0487426 & -.0399159 & -.0354406 \\
\hline & $(0.090)$ & $(0.091)$ & $(0.260)$ \\
\hline \multirow[t]{2}{*}{ GDP } & 0219007 & .0044785 & 0374488 \\
\hline & $(0.732)$ & $(0.930)$ & $(0.410)$ \\
\hline \multirow[t]{2}{*}{ Concentration } & $.0000461^{*}$ & -.0000811 & 0000916 \\
\hline & $(0.000)$ & $(0.089)$ & $(0.072)$ \\
\hline \multirow[t]{2}{*}{ Constant } & -.0168437 & .0148879 & -.0302812 \\
\hline & $(0.926)$ & $(0.931)$ & $(0.820)$ \\
\hline Observations & 190 & 190 & 190 \\
\hline R-squared & 0.5245 & 0.4922 & 0.4276 \\
\hline \multirow[t]{2}{*}{ STD } & $.3168831 * *$ & $.1329073 * *$ & .1910135 \\
\hline & $(0.003)$ & $(0.023)$ & $(0.101)$ \\
\hline \multirow[t]{2}{*}{ Asset Size } & $.3594392 * *$ & $.3230243^{*}$ & $.4764744 *$ \\
\hline & $(0.000)$ & $(0.000)$ & $(0.000)$ \\
\hline \multirow[t]{2}{*}{ Firms Age } & .0001964 & .0003643 & $-.0013023 * *$ \\
\hline & $(0.683)$ & $(0.614)$ & $(0.022)$ \\
\hline \multirow[t]{2}{*}{ Sales Growth } & $.5032973 *$ & $.5467769^{*}$ & $.3678859 *$ \\
\hline & $(0.000)$ & $(0.000)$ & $(0.000)$ \\
\hline \multirow[t]{2}{*}{ Inflation Rate } & $-.0710981 * *$ & $-.0665168 * *$ & -.0585694 \\
\hline & $(0.020)$ & $(0.014)$ & $(0.091)$ \\
\hline \multirow[t]{2}{*}{ Growth } & .0131669 & -.0172588 & .0214549 \\
\hline & $(0.866)$ & $(0.803)$ & $(0.695)$ \\
\hline \multirow[t]{2}{*}{ Concentration } & $0000856 * *$ & -.0000363 & .0000354 \\
\hline & $(0.003)$ & $(0.174)$ & $(0.151)$ \\
\hline \multirow[t]{2}{*}{ Constant } & .0475607 & .1822649 & .0909599 \\
\hline & $(0.819)$ & $(0.385)$ & $(0.523)$ \\
\hline Observations & 190 & 190 & 190 \\
\hline R-squared & 0.4895 & 0.4756 & 0.4660 \\
\hline \multirow[t]{2}{*}{ (ETQ) } & $.2572869 * *$ & $.239641 * *$ & $.2851213 * *$ \\
\hline & $(0.002)$ & $(0.010)$ & $(0.003)$ \\
\hline \multirow[t]{2}{*}{ Asset Size } & $.3848888^{*}$ & $.3050643 *$ & $.4756827 *$ \\
\hline & $(0.000)$ & $(0.000)$ & $(0.000)$ \\
\hline \multirow[t]{2}{*}{ Firms Age } & .0004091 & .000471 & -.0012197 \\
\hline & $(0.458)$ & $(0.530)$ & $(0.032)$ \\
\hline \multirow[t]{2}{*}{ Sales Growth } & $.5235829 *$ & $.5240197 *$ & $.3335743 *$ \\
\hline & $(0.000)$ & $(0.000)$ & $(0.000)$ \\
\hline \multirow[t]{2}{*}{ Inflation Rate } & -.0578103 & $-.0544365 * *$ & -.0451883 \\
\hline & $(0.063)$ & $(0.039)$ & $(0.195)$ \\
\hline \multirow[t]{2}{*}{ Growth } & -.014871 & -.0374072 & -.0019554 \\
\hline & $(0.833)$ & $(0.569)$ & $(0.971)$ \\
\hline
\end{tabular}




\begin{tabular}{cccc}
\hline Concentration & $.0000972 *$ & -0000131 & .0000422 \\
\hline & $(0.000)$ & $(0.618)$ & $(0.061)$ \\
\hline Constant & .083537 & .158873 & .0795566 \\
\hline & $(0.673)$ & $(0.477)$ & $(0.584)$ \\
\hline Observations & 190 & 190 & 190 \\
\hline R-squared & 0.4737 & 0.4906 & 0.4875 \\
\hline
\end{tabular}

Standard errors in parentheses

$* * \mathrm{p}<0.05, * \mathrm{p}<0.1$

This study examined the relationship between capital structure, proxy by long term debt, short term debt and equity financing, and the performance of insurances Jordan companies during the period of 2007-2016. Three regression models were used to test the relationship.

The result from Table 3 shows that capital structure has a significant statistical impact on financial performance, ROA, and ROE. This is supported by many previous studies (Shamsuddin, et al., 2018; Gambo et al. 2016; Akingunola \& Olaniyan, 2018; Risfandy, 2018; Ashraf et, al. 2017; Basit \& Hassan, 2017) which stated that an increase in the capital structure has a significant impact on their performance. Capital structure that is proxy by long term debt and equity financing shows a positive significant relationship to ROE, ROA, and Tobin's Q. Meanwhile, short term debt only significant to ROE and ROA, but has no significant relationship with Tobin'Q. This finding implies that the use of longterm debt and equity financing is more beneficial to the owners of capital in insurance firms in Jordan. This finding implies that the use of long-term debt is beneficial to the owners of capital in insurance firms in Jordan. Longer-term debt usually requires a slightly higher interest rate than shorter-term debt. However, a company has a more extended amount of time to repay the principal with interest. The financial risk in the use of long-term debt among insurance firms implies that equity owners get high-risk premium plus the return on the capital.

The results also consistent with agency cost theory Jensen \& Meckling (1976) suggested that for an optimal debt level in capital structure by minimizing the agency costs arising from the divergent interest of managers with shareholders and debt holders. They suggest that either ownership of the managers in the firm should be increased to align the interest of managers with that of the owners or users of debt should be motivated to control managers' tendency for excessive extra consumption. Therefore, firms that are mostly financed by debt has given managers less decision power of those financed mostly by equity, and thus debt can be used as a control mechanism, in which lenders and shareholders become the principal parties in the corporate governance structure.

The results from Table 3 showed a significant positive relationship between equity financing and performance ROE, ROA, and Tobin's Q of Insurance firms in Jordan. The advantages of using equity financing are equity financing does not require the company to issue collateral and additional financing of shares does not increase the likelihood of financial distress. This finding is in line with the study by Ahmed \& Siddiqui (2019) found in their study that highly profitable insurance companies have more likely relied on internally generated funds and equity capital than debt capital as the source of financing. Practically, well-capitalized insurance companies face lower costs of going bankrupt, which reduces their cost of funding or that they have lower needs for external funding which results in higher performance.

Regarding the control variables, asset size and sales growth have a significant positive relationship with ROA, ROE, and Tobin's Q. Firms' age has a significant negative relationship only with Tobin's Q. A percent decrease in the age of the company resulted in an $-0.141 \%$ percent decrease in Tobin's Q. Pecking order theory suggests a negative relationship between age and debt. Thus, older firms are more likely to use internal funds rather than both long term and short-term funds. Whereas, market concentration has a significant positive relationship only to ROE.

\section{CONCLUSION}

This study aims to provide empirical evidence regarding the influence of capital structure on the performance of the Insurance sector in Jordan. This study concluded that the capital structure represented by long term debt and equity financing have a significant impact on insurance firm financial performance (ROE, ROA, and Tobin's Q). Whilst, short term debt only has a significant impact on ROE and ROA.

Long-term debt has a significant positive relationship with return on equity and returns on assets. A percent increase in long-term debt resulted in a $36.129 \%$ percent increase in return on equity, as well as a percent increase in long-term debt resulted in a $45.009 \%$ percent increase in the return on assets. Also, long-term debt has a significant positive relationship with Tobin's Q. A percent increase in long-term debt resulted in a 38.804\% percent increase in Tobin's Q. The results are consistent with the trade-off theory and agency cost theory and predict that profitable firms depend on debt. Regarding the control variables, asset size, firm's age, sales growth, and market concentration have a significant positive relationship with long-term debt. 
Short-term debt has a significant positive relationship with return on equity and returns on assets. A percent increase in long-term debt resulted in a $31.688 \%$ percent increase in return on equity, as well as a 13.290 percent increase in the return on assets. However, a relationship between short-term debt and Tobin's Q is not statistically significant. Regarding the control variables, asset size, firm's age, sales growth, Inflation rate, and Concentration have a significant positive relationship with short-term debt. The results are consistent with the trade-off theory, which posits that an optimal capital structure is formed by a trade-off (a counterbalancing situation) between advantages of debt financing and the risk of financial distress or bankruptcy.

A percent increase in equity financing resulted in a $25.728 \%$ percent increase in return on equity, as well as a percent increase in equity financing resulted in a $23.964 \%$ percent increase in the return on assets and resulted in a $28.512 \%$ percent increase in Tobin's Q. Regarding the control variables, namely, asset size, firm age, sales growth, inflation rate, and market concentration have a significant positive relationship with equity financing. The results are consistent with the trade-off theory, posits that a company selects on its capital structure by equalizing the costs and benefits of debt and equity.

\section{LIMITATION AND STUDY FORWARD}

This study can be extended by adding more sectors, especially financial companies, service companies, and non-listed companies. Further research recommendation includes conducting a comparative study to check the relationship between capital structure and performance of foreign and domestic insurance companies in Jordan. This will provide a baseline for future researches relating to the capital structure of Jordanian insurance companies. This study sample is limited to 19 insurance companies instead of a total of 24 insurance companies due to the limited availability of data.

\section{ACKNOWLEDGMENT}

This work was partially supported by the Universiti Sultan Zainal Abidin, Kuala Terengganu, Malaysia, Research Grant (Vote No. R0018-R366).

\section{REFERENCES}

1. Abrar, A., \& Javaid, A. Y. (2016). The Impact of Capital Structure on the Profitability of Microfinance Institutions. South Asian Journal of Management, 10(1), 21-37. https://doi.org/10.21621/SAJMS.2016101.03

2. Ahmad, N., \& Abdul-Rahim, F. (2013). Theoretical investigation on determinants of government-linked company's capital structure. Journal of Accounting, Finance and Economics, 3(2), 72-85.

3. Abeywardhana, D. K. Y., \& Krishanthi, D. (2016). Impact of capital structure on firm performance: Evidence from Manufacturing Sector SMEs in UK. DOI: 10.2139/ssrn.2816499. https://doi.org/10.2139/ssrn.2816499

4. Akingunola, R. O., Olawale, L. S., \& Olaniyan, J. D. (2018). Capital Structure Decision and Firm Performance: Evidence from Non-Financial Firms in Nigeria. Acta Universitatis Danubius. Economica, 13(6). https://doi.org/10.5296/ijafr.v7i2.12455

5. Ali, A., Ullah, A., Shah, P. Q., Shehzad, N., \& Nawab, W. (2016). Impact of Capital Structure on Profitability: A Comparative Study of Cement \&Automobile Sector of Pakistan. Journal of Managerial Sciences Volume X Number, 1, 120. https://doi.org/10.2139/ssrn.2732408

6. Alomari, M. W., \& Azzam, I. (2017). Effect of the micro and macro factors on the performance of the listed jordanian insurance companies. International Journal of Business and Social Science, 8(2), 66-73. https://doi.org/10.30845/ijbss

7. Anarfo, E. B. (2015). Capital Structure and Bank Performance-Evidence from Sub-Sahara Africa. European Journal of Accounting, Auditing and Finance Research,3(3), 1-20. https://doi.org/10.18488/journal.aefr/2015.5.4/102.4.624.640

8. Anarfo, E. B., \& Appiahene, E. (2017). The Impact of Capital Structure on Banks' Profitability in Africa. Journal of Accounting and Finance, 17(2), 55-66.

9. Ashraf, M., Ameen, A., \& Shahzadi, K. (2017). The Impact of Capital Structure on Firm's Profitability: A Case of Cement Industry of Pakistan. International Journal of Business and Social Science, 8(4). https://doi.org/10.5897/AJBM11.2103

10. Olang, M. (2017). The effect of financial leverage on profitability of firms listed at Nairobi securities exchange. International Journal of Science \& Research, 6(7), 290-295. https://doi.org/10.21275/ART20175033

11. Basit, A., \& Hassan, Z. (2017). Impact of capital structure on firm's performance: a study on Karachi Stock Exchange (KSE) listed firms in Pakistan. Basit, A., \& Hassan, (2017), 118-135. https://ssrn.com/abstract=2945807

12. Burja, C. (2011). Factors influencing the companies profitability. Annales Universitatis Apulensis: Series Oeconomica, 13(2), 215.

13. Gambo, E. M. J., Abdul-Rahman, A., \& Ahmad, M. M. (2016). Capital structure and firm performance in the Nigerian cement industry. Archives of Business Research, 4(6). https://doi.org/10.14738/abr.46.2367

14. Martati, I., \& Kusrihandayani, D. (2018). The Effect of Capital Structure on Profitability of Manufacturing Company. Advanced Science Letters, 24(12), 9372-9375. https://doi.org/10.1166/asl.2018.12277 
15. Girod, S. J., \& Whittington, R. (2017). Reconfiguration, restructuring and firm performance: Dynamic capabilities and environmental dynamism. Strategic Management Journal, 38(5), 1121-1133. https://doi.org/10.1002/smj.2543

16. Habib, H., Khan, F., \& Wazir, M. (2016). Impact of Debt on Profitability of Firms: Evidence from NonFinancial Sector of Pakistan, City University Research Journal, 6 (1), 70-80.

17. https://papers.ssrn.com/sol3/papers.cfm?abstract id=2945807

18. Hamid, M. A., Abdullah, A., \& Kamaruzzaman, N. A. (2015). Capital structure and profitability in family and non-family firms: Malaysian evidence. Procedia Economics and Finance, 31, 44-5. https://doi.org/10.1016/S2212-5671(15)01130-2

19. Jensen, M. C. (1986). Agency costs of free cash flow, corporate finance, and takeovers. The American Economic Review, 76(2), 323-329. https://doi.org/10.1017/CB09780511609435.005

20. Kirmi, P. N. (2017). Relationship between capital structure and profitability, evidence from listed energy and petroleum companies listed in Nairobi Securities Exchange. Journal of Investment and Management, 6(5), 97102. https://doi.org/10.11648/j.jim.20170605.11

21. Murniati, S. (2016). Effect of Capital Structure, Company Size and Profitability on the Stock Price of Food and Beverage Companies Listed on the Indonesia Stock Exchange. Information Management and Business Review, 8(1), 23-29. https://doi.org/10.22610/imbr.v8i1.1192

22. Marandu, K. R., \& Sibindi, A. B. (2016). Capital structure and profitability: An empirical study of South African banks. Corporate Ownership and Control, 14(1), 8-19. https://doi.org/10.22495/cocv14i1p1

23. Martinkute-Kauliene, R., \& Rinkevičiūtè, V. (2014). Impact of market concentration on the profitability of Lithuanian banking sector. Business: Theory and Practice, 15, 254. https://doi.org/10.3846/btp.2014.25

24. Muritala, T. A. (2018). An empirical analysis of capital structure on firms' performance in Nigeria. IJAME. ISSN: 2278-3369.

25. Patjoshi, P. (2016). A Study on Liquidity Management and Financial Performance of Selected Steel Companies in India. International Journal of Advanced Information Science and Technology, 5(7), pp 108-117.

26. Revathy, S., Santhi, V., \& Sreekala, S. (2016). The Impact of Capital Structure on Profitability of Manufacturing Companies: using Multiple Regression Model. Asian Journal of Research in Social Sciences and Humanities, 6(4), 306-315. https://doi.org/10.5958/2249-7315.2016.00060.5

27. Risfandy, T. (2018). Equity Financing and Islamic Banks' Profitability: Evidence From the Biggest Muslim Country. Jurnal Keuangan dan Perbankan, 22(3). https://doi.org/10.26905/jkdp.v22i3.2150

28. Ahmed, F., \& Siddiqui, D. A. (2019). Impact of Debt Financing on Performance: Evidence from Textile Sector of Pakistan. Available at SSRN 3384213. https://doi.org/10.2139/ssrn.3384213

29. Shamsuddin, Z., Ismail, A. G., Yusoff, W.S., Mahmood, S., and Wan Daud, W.M.N. (2018) Capital structure, investment, members return, and performance: some Malaysian cooperative evidence. National Academy of Managerial Staff of Culture and Arts Herald, 927-931. https://scholar.google.com/citations?user=wqbr14MAAAAJ\&hl=en

30. Shubita, M. F., \& Alsawalhah, J. M. (2012). The relationship between capital structure and profitability. International Journal of Business and Social Science, 3(16). https://doi.org/10.30845/ijbss

31. Siddik, M. N. A., Kabiraj, S., \& Joghee, S. (2017). Impacts of capital structure on performance of banks in a developing economy: evidence from Bangladesh. International Journal of Financial Studies, 5(2), 13. https://doi.org/10.3390/ijfs5020013

32. Singh, S., Tabassum, N., Darwish, T. K., \& Batsakis, G. (2018). Corporate governance and Tobin's Q as a measure of organizational performance. British Journal of Management,29(1), 171-190. https://doi.org/10.1111/1467-8551.12237

33. Bahkia, A. S., Awang, Z., Afthanorhan, A., Ghazali, P. L., \& Foziah, H. (2019). Exploratory factor analysis on occupational stress in context of malaysian sewerage operations. Paper presented at the AIP Conference Proceedings, , 2138. https://doi.org/10.1063/1.5121111

34. Majid, N. A., Zainol, F. A., Wan Daud, W. N., \& Afthanorhan, A. (2019). Cooperative entrepreneurship in malaysian secondary schools: A review of current practices. Journal of Social Sciences Research, 5(3), 812818. https://doi.org/10.32861/jssr.53.812.818

35. Suardana, I. B. R., Astawa, I. N. D., \& Martini, L. K. B. (2018). Influential factors towards return on assets and profit change. International journal of social sciences and humanities, 2(1), 105-116. https://doi.org/10.29332/ijssh.v2n1.100

36. Zeitun, R., \& Tian, G. G. (2014). Capital structure and corporate performance: evidence from Jordan. Australasian Accounting Business \& Finance Journal, Forthcoming. https://doi.org/10.7176/RJFA/1020-07

37. Ai, W., \& Chi, B. (2019). The Impact of Capital Structure on Financial Performance of Real Estate Enterprises under Deleveraging. In ICCREM 2019: Innovative Construction Project Management and Construction Industrialization (pp. 759-765). Reston, VA: American Society of Civil Engineers. https://doi.org/10.1061/9780784482308.088 
38. Venugopal, M., \& Reddy, M. R. (2016). Impact of capital structure on firm's profitability and shareholder wealth maximization: A study of listed Indian cement companies. IOSR Journal of Business and Management, 18(4), 21-27. https://doi.org/10.15410/cijbr/2015/v1i1/61401

39. Takele, Y., \& Beshir, D. (2017). Firm-Specific Determinants of Insurance Companies' Capital Structure in Ethiopia. In Studies on Economic Development and Growth in Selected African Countries (pp. 155-175). Springer, Singapore. https://doi.org/10.21275/ART20164109

40. Hirdinis, M. (2019). Capital structure and firm size on firm value moderated by profitability. https://doi.org/10.35808/ijeba/204

41. Zafar, M. R., Zeeshan, F., \& Ahmed, R. (2016). Impact of capital structure on banking profitability. International Journal of Scientific and Research Publications, 6(3), 186-193.

42. Zeitun, R., \& Tian, G. G. (2014). Capital structure and corporate performance: evidence from Jordan. Australasian Accounting Business \& Finance Journal, Forthcoming. https://doi.org/10.14453/aabfj.v1i4.3 